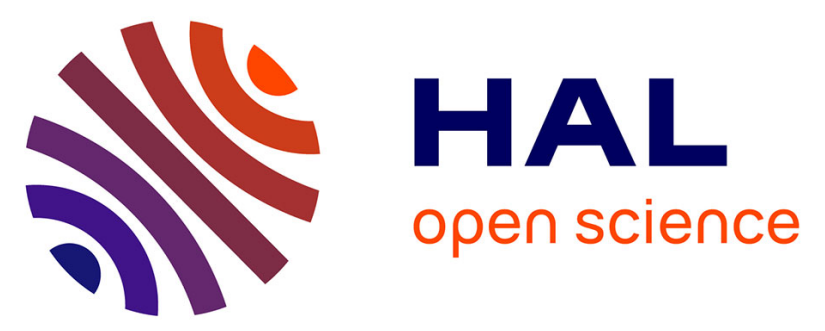

\title{
Spatial and temporal changes in infaunal communities inhabiting soft-bottoms affected by brine discharge
} Y. del Pilar Ruso, J.A. de La Ossa Carretero, F. Giménez Casalduero, J.L. Sánchez Lizaso

\section{- To cite this version:}

Y. del Pilar Ruso, J.A. de La Ossa Carretero, F. Giménez Casalduero, J.L. Sánchez Lizaso. Spatial and temporal changes in infaunal communities inhabiting soft-bottoms affected by brine discharge. Marine Environmental Research, 2007, 64 (4), pp.492. 10.1016/j.marenvres.2007.04.003 . hal-00501916

\section{HAL Id: hal-00501916 https://hal.science/hal-00501916}

Submitted on 13 Jul 2010

HAL is a multi-disciplinary open access archive for the deposit and dissemination of scientific research documents, whether they are published or not. The documents may come from teaching and research institutions in France or abroad, or from public or private research centers.
L'archive ouverte pluridisciplinaire HAL, est destinée au dépôt et à la diffusion de documents scientifiques de niveau recherche, publiés ou non, émanant des établissements d'enseignement et de recherche français ou étrangers, des laboratoires publics ou privés. 


\section{Accepted Manuscript}

Spatial and temporal changes in infaunal communities inhabiting soft-bottoms affected by brine discharge

Y. Del Pilar Ruso, J.A. De la Ossa Carretero, F. Giménez Casalduero, J.L. Sánchez Lizaso

PII:

S0141-1136(07)00059-1

DOI: 10.1016/j.marenvres.2007.04.003

Reference: MERE 3118

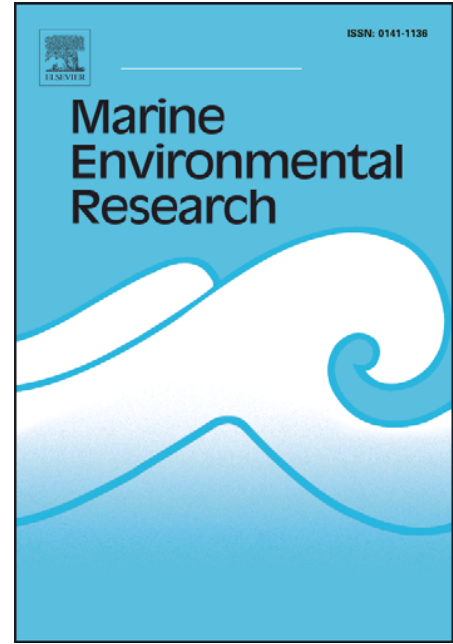

To appear in:

Marine Environmental Research

Received Date:

20 October 2006

Revised Date:

11 April 2007

Accepted Date:

12 April 2007

Please cite this article as: Del Pilar Ruso, Y., De la Ossa Carretero, J.A., Giménez Casalduero, F., Sánchez Lizaso, J.L., Spatial and temporal changes in infaunal communities inhabiting soft-bottoms affected by brine discharge, Marine Environmental Research (2007), doi: 10.1016/j.marenvres.2007.04.003

This is a PDF file of an unedited manuscript that has been accepted for publication. As a service to our customers we are providing this early version of the manuscript. The manuscript will undergo copyediting, typesetting, and review of the resulting proof before it is published in its final form. Please note that during the production process errors may be discovered which could affect the content, and all legal disclaimers that apply to the journal pertain. 
Spatial and temporal changes in infaunal communities inhabiting soft-bottoms affected by brine discharge.

Y. Del Pilar Ruso**a, J.A. De la Ossa Carretero ${ }^{\text {a }}$, F. Giménez Casalduero a , J.L. Sánchez Lizaso $^{\mathrm{a}}$.

${ }^{a}$ Dpto. de Ciencias del Mar y Biología Aplicada. Universidad de Alicante. Campus de San Vicente del Raspeig, Ap. 99. E-03080, Alicante.

* Corresponding author. Tel. +34 965.90.34.00- Ext. 2916-Fax: 965.90.98.40

E-mail: yoana.delpilar@ua.es 


\section{Abstract}

The discharge of an effluent of high salinity from reverse osmosis desalination plants has a strong impact on marine communities. The aim of this study was to examine the effect of brine discharge over soft bottom communities along the Alicante coast (Southeast Spain) over a two year period. Changes in the infaunal assemblage were analysed using univariate and multivariate techniques. Each year we sampled along three transects at three depths $(4,10$ and $15 \mathrm{~m})$ during winter and summer. We observed a substitution of a community characterized by the presence of Polychaeta, Crustacea and Mollusca, for another dominated by nematodes (up to $98 \%$ ), in the stations closer to the discharge where salinity values exceed $39 \mathrm{psu}$.

Keywords: Salinity; Brine discharge; Infaunal community; Mediterranean Sea; Desalination; Environmental impact 


\section{INTRODUCTION}

Desalination of seawater has become an important and growing industry due to the water shortage in certain Mediterranean countries. The reverse osmosis process is the most common desalination method employed because of its high energetic efficiency. The main impact on marine communities of reverse osmosis desalination plants is caused by the discharge of an effluent of very high salinity (70-90 psu). The magnitude of the impact will depend both on the size of the plant and on the sensitivity of the ecosystem that receives the spill (Höpner and Windelberg, 1996). Brine discharge remains on the bottom because of its high density and it may affect marine benthic communities. Marine organisms live in an osmotic balance with their environment and an increase in salt concentration may result in the dehydration of cells, a decrease of the turgor pressure, and ultimately death, of mainly larvae and young individuals (Einav et al., 2002).

Several studies have been undertaken of the socio-economic and environmental impacts of desalination plants (Höpner and Windelberg, 1996; Einav et al., 2002; García and Servera, 2003; Al Malek and Mohamed, 2005; Areiqat and Mohamed, 2005; Elabbar and Elmabrouk, 2005; Meerganz Von Medeazza, 2005; Purnama et al., 2005; Sadhwani

et al., 2005). Nevertheless, there have been very few studies dealing with the impact of hypersaline brine inputs on benthic communities. The few reports that are available indicate that brine discharges caused reduction of fish populations, plankton and coral die-off in the Red Sea (Mabrook, 1994). It also increased mortality in mangrove and marine angiosperm in the Ras Hanjurah lagoon in the United Arab Emirates (Vries et 
al., 1997) and magnified pollution levels due to the increase of copper and nickel levels at Key West, Florida (Chesher, 1975). In addition, some authors have analysed the effect of this new impact on seagrasses (Buceta et al., 2003; Fernández-Torquemada and Sánchez Lizaso, 2005; Fernández-Torquemada et al., 2005a, 2005b). However, studies on the effects on infaunal communities of sandy bottoms are scarce (Raventos et al, 2006), although, many such habitats are to be found in proximity to brine discharge, and authors like Höpner and Winddelber (1996) defined these areas as those of least sensitivity to the effects of brine discharge.

The present study has focused on the Alicante desalination plant, where the reverse osmosis technique is employed. The discharge takes place in a coastal zone, with high levels of hydrodynamic activity. This desalination plant began operations in September 2003. Initially it had seven lines and a fresh water production capacity of $50,000 \mathrm{~m}^{3} /$ day and a discharge of $65,000 \mathrm{~m}^{3} /$ day. The discharge is characterized by its high salinity ( 68 psu) and low nutrient content. 


\section{MATERIALS AND METHODS}

The study was carried out in waters facing the Alicante desalination plant of (SW Spain) (Figure 1). In this area, there is a north-south pollution gradient, caused by sewage outfall and port activities situated around $2.5 \mathrm{~km}$ to the north of the desalination discharge. For these reasons three perpendicular transects to the coast were established, one directly in front of the discharge (transect B), one $400 \mathrm{~m}$ to the north (transect A) and the other $400 \mathrm{~m}$ to the south (transect C) (Figure 1). Three stations at 4, 10 and 15 meter depths were sampled at each transect, in winter and summer during 2004 and 2005.

Sampling was carried out by SCUBA diving. To study infaunal community three replicates were collected at each station using a square box $(22.5 \times 22.5 \mathrm{~cm})$, sieved through a $0.5 \mathrm{~mm}$ mesh screen and preserved in buffered formalin. An additional sample was collected at each station with a corer $(20 \mathrm{~cm}$ diameter, $10.5 \mathrm{~cm}$ deep) for sediment analysis. Immediately after its collection, $\mathrm{pH}$ was measured in undisturbed sediment cores using a pH-meter Crison with a sensor 52-00. Once in the laboratory, the sediment was dried in an oven. One sub-sample was used for granulometric analysis following Buchanan's methodology (1984). Another sub-sample was used to obtain organic matter percentage. Organic matter content of dry sediment was estimated by loss of mass on ignition after being ashed at $400^{\circ} \mathrm{C}$ for $4 \mathrm{~h}$. Salinity surveys were made in summer and winter of both years by means of a sonde Hydrolab H20. 
To test differences in abundance, number of taxonomic groups and diversity in the infaunal assemblage among the four fixed orthogonal factors considered: year (2004 and 2005), season, with two levels (summer and winter); transect, with three levels (A, B, C) and depth, with three levels (4, 10 and $15 \mathrm{~m}$ ), an analysis of variance (ANOVA; Underwood, 1981) was used. Heterogeneity of variance was tested with Cochran's test (Underwood, 1997). Data were $\sqrt{ } X+1$ transformed if variances were significantly different at $\mathrm{p}=0.05$, and $\ln (\mathrm{X}+1)$ transformed if variance was still heterogeneous. Where variance remained heterogeneous, untransformed data were analysed; as ANOVA is robust to heterogeneity of variances, particularly for large balanced experiments (Underwood, 1997). Further, we set the F-test alpha at 0.01 for analyses which used untransformed data. SNK test (Student-Newman-Keuls) was used to determine which samples were implicated in the differences (Underwood, 1981).

Non-parametric multivariate techniques were used to compare different taxonomic groups present in the study area. All multivariate analyses were performed using the PRIMER statistical package (Clarke y Warwick, 1994). Triangular similarity matrices were calculated using the Bray-Curtis similarity coefficient (Clarke and Warwick, 1994) using abundance values. Graphical representation of multivariate patterns of infaunal assemblages was obtained by non-metric multidimensional scaling (nMDS). Correlation between infaunal data and abiotic factors (sediment grain size, organic matter, $\mathrm{pH}$, depth and salinity) were determined using the RELATE procedure (Clarke, 1993). Similarity percentages (SIMPER) procedure was used to determine the percentage contribution of each infaunal group. 


\section{RESULTS}

The study area is characterized by the heterogeneity of sediments. Medium and fine sand fraction dominate in the shallower stations (4 meters), while in the deeper ones (10 and 15 meters) mud fraction was more abundant. The B2 station was characterized by the presence of a high percentage of gravels and coarse sand. The $\mathrm{pH}$ values ranged between 7.01 and 7.94. Organic matter percentages ranged between $1 \%$ and $22.7 \%$. The lowest values were obtained in the shallow stations. The salinity was around $37.9 \pm 0.09$ in all the stations with the exception of stations closer to the discharge. In station B2, at $10 \mathrm{~m}$ depth, average salinity is $38.9 \pm 0.17$ and in station B1 at $4 \mathrm{~m}$ salinity values exceed 40 psu (Table 1).

With regard to the infaunal community, a total of 13,323 specimens were collected, and divided into 20 different taxonomic groups. The higher taxonomic level was used, in order to consider the Taxonomic sufficiency, where the identifying taxa should be undertaken only to the taxonomic level sufficient for the purpose of the study (Ellis, 1985). The invertebrate taxa represented in this study were Amphipoda, Ascidiacea, Asteroidea, Bivalvia, Cephalochordata, Copepoda, Cumacea, Decapoda, Echinoidea, Gasteropoda, Holoturoidea, Isopoda, Mysidacea, Nematoda, Ostracoda, Polychaeta, Pycnogonida, Scaphopoda, Sipunculida, and Tanaidacea.

The results of abundance analyses detected significant differences for the interaction among three factors (Year $x$ Season $x$ Transect) $(\mathrm{p}=0.0217)$ (Table 2). These differences were due to the increase of abundance in the transect B during summer 
2005. This increase was more evident in B1 and B2 (Figure 3). Analyzing the number of taxonomic groups, significant differences were detected between seasonal periods ( $p$ =0) (Table 2) with more taxonomic groups detected during the summer (Figures 6). Differences were also detected for the interaction among the factors: year, transect and depth $(p=0.0237)$. These differences are due to the decrease in the number of taxonomic groups in transects B and C. This decrease is more evident in the shallower stations of transect $\mathrm{C}$ during the first year, and of transect $\mathrm{B}$ during the second year of the activity (Figure 4). Significant differences were detected for the interaction among the four factors (Year $x$ Season $x$ Transect $x$ Depth) for the diversity $(p=0.0166)$. These differences were due to the increase of the diversity during the summer in both years, except in B1 and B2, where it decreases during the summer of the last year. At these stations the lowest values are obtained (Figure 5).

At the beginning, Polychaetes were the most abundant group (38.5\% of the total), followed by Nematodes (34.6\%) and Bivalvia (12.4\%) (Figure 2). This situation remains in all stations, except in the closest station to the discharge (B1). In this station the community is dominated by Nematode from the second sampling time (S04). Something similar began to occur in station A1 as of the winter of the second year and in station B2 during the last campaigns (summer, 2005) (Figure 2).

Analyzing the MDS plot (Figure 6), we can observe changes in the structure of the infauna. On the one hand, it is possible to observe the existence of a highly homogenous group (Group I), consisting of most of the stations during the different sampling periods. Group I is characterized by the presence of Polychaeta, Bivalve and Decapods. The results show a segregation of the station closer to the discharge (B1) with regard to 
the stations included in group I, from the beginning of the activity (Figure 6) The decrease of Polychaeta, Bivalvia, Decapoda, Amphipoda and increase of Nematoda (Figure 2) were mainly responsible for the dissimilarities between station B1 and group I. These differences increase with time $(68.7 \%$ in the winter of $2004,659 \%$, in the summer of 2004, 83\%, in the winter of 2005 and $96.25 \%$, in the summer of 2005). During the second year of activity, we observed changes in the infaunal community in the A1 and C1 stations (Figures 2 and 6). The decrease in the abundance of Polychaeta, Bivalvia, Amphipoda and increase of Decapoda were responsible for the dissimilarities observed in the C1 station, while increase of abundance of Nematoda and decrease of Polychaeta, Bivalvia and Tanaidacea marked the differences between the A1 station and the rest (Figure 2). Finally, in summer 2005, we observe changes in the structure of the community of station B2 (Figures 6). In this station, Polychaeta abundance decreases while Nematode abundance increased (87.8\% dissimilarity) (Figure 2).

A positive correlation is observed between the infauna and the factors depth $(\mathrm{Rho}=0.289 ; \mathrm{p}<0.01)$, organic matter $(\mathrm{Rho}=0.141 ; \mathrm{p}<0.05)$, salinity $(\mathrm{Rho}=0.32$; $\mathrm{p}<0.01)$, medium sands $(\mathrm{Rho}=0.27 ; \mathrm{p}<0.01)$, fine sands $(\mathrm{Rho}=0.068 ; \mathrm{p}<0.05)$ and mud $($ Rho=0.124; $\mathrm{p}<0.01)$ (figure 7).

\section{DISCUSSION}

Benthic infaunal communities are widely used as indicators of habitat conditions and for the detection of human induced change in marine environments (Bilyard, 1987). The ubiquity of macroinvertebrates in ecosystems coupled with the wide range of sensitivities exhibited by different taxa to environmental stresses makes them an 
attractive choice (Weiss and Reice, 2005). Desalination is an activity that induced a new impact, brine discharge, in a place where the salinity values were once stable. This abrupt change of salinity may affect the benthic community. It is reasonable to assume that stations within the area of influence of outflows from the desalination plant present communities which are more similar to hypersaline areas than to the lower-salinity coastal areas. Significant variations of salinity can probably cause substitution of some species and/ or communities for others. Under natural conditions the increments of salinity in the Mediterranean marine environment are rare and they usually take place in dynamic gradient estuaries or closed systems (lagoons, wetlands, swamps). These hypersaline systems are characterized by low diversity (it has been observed that above 38 psu the number of species decrease considerably), and often, high productivity. These communities are simplified and they are completely different to the adjacent coastal areas chracterized by much more constant environmental conditions (García and Ballesteros, 2001). Chesher (1975) describes, in an environmental impact assessment of a desalination plant in Key West (Florida), the disappearance of the original communities and their substitution for a few organisms characteristic of stress situations.

In this sense, desalination activity causes changes in abundance, number of taxonomic groups and diversity in infaunal communities of the study area, firstly in the vicinity of outfalls (B1), where influence of the brine discharge is higher (Figure 5) and in addition, it causes an impoverishment of community. In this area diversity and the number of taxonomic groups decrease, while the abundance of nematode, increases. We observed a substitution of a community characterized by the presence of Polychaeta, Crustacea and Mollusca, for another dominated by nematodes (up to $98 \%$ ), in the stations where salinity values exceed 39 psu. In the station closer to the discharge (B1), 
the change in the structure of the community can be observed after nine months from the beginning of the activity (July 2004). In station B2, located at $400 \mathrm{~m}$ from the discharge and at 10 meters depth, similar changes were observed after the second year of activity (July 2005) and may be interpreted as an extension of the area of influence of the discharge. However, sampling over a longer period will be necessary to confirm that this trend is consistent with time. These changes could be caused by the influence of brine since they are observed in the stations with higher salinity values although it is necessary to be cautious due to the heterogeneity of the sediment and the north-south gradient pollution of the area. Thus, it is difficult to single out the effect of salinity. Changes in the composition of the infaunal community observed during the second year in the station A1 are probably due to other factors, unrelated to the brine discharge since the salinity at this station does not exceed 38.4 psu. This station is closer to a sewage outfall and the Alicante harbour that has recently undergone expansion. In spite of the heterogeneity of the area, most of stations and sampling times are grouped in MDS. Therefore, the clearest effect of the brine is the consistent change in the fauna in station B1 at the site of the discharge. This can be seen both in Figure 2 where the nematodes continuously increase in importance and in the MDS in Figure 6, where the distance between station B1 and the rest consistently increases. Castriota et al., (2001) also observed, after one year, that the hypersaline and heated plume affected the organisms living near the diffuser. They recorded major effects on abundance that decreased at the discharge site for all the groups examined, particularly, crustaceans, molluscs, in much the same way as we observed. Moreover, it was observed that echinoderms nearly disappeared. By comparison however, Raventos et al., (2006) found no significant variations attributable to the brine discharges from a small desalination plant. The failure to detect any impact in this study may be explained by the smaller size of the 
plant that facilitates the rapid dilution of the brine and the high natural variability that is a characteristic feature of soft bottoms.

Changes observed in the community demonstrate that analysis of the impact of high taxonomic levels show interesting results. Differences in communities have been detected in other studies where fauna were aggregated to higher taxonomic levels, family or even phylum, (Warwick, 1988 a,b; Ferraro and Cole, 1992; Olsgard et al., 1997). Warwick (1988 a,b) proposed that the ability to separate the "signal" of an impact from the "noise" of natural environmental variables (e.g. depth, and sediment grain size) is more clear cut and reliable at taxonomic level higher than species. Studies of marine benthic communities have shown that pollution impacts can often be detected without identifying taxa to the species level, thus saving considerable time and cost (Dethier and Schoch, 2006).

Knowledge of the existence of an environmental stress situation is the prerequisite for its solution. In view of the different time scales of the resultant strains and their complex nature, early recognition of such situations is necessary before changes and damage become wide-spread and obvious (Fränzle, 2006). In order to minimise the impact of reverse osmosis desalination plants, any change in the disposal that increases the mixing of the brine will be positive since it will reduce the area affected by higher salinity levels. The use of diffusers or the prior mixing with seawater have been successful in achieving these objectives in some desalinations plants (Fernández Torquemada et al, 2004) 


\section{Acknowledgements:}

This work was funded by the Mancomunidad de los Canales de Taibilla. Thanks to all staff of the Marine Biology Laboratory at the University of Alicante, for their assistance with this work, particularly Yolanda Fernández Torquemada, Marta Díaz-Valdés, Cristina Celdrán Martinez, Angel Loya, and Yolanda Múgica. Thanks are due to Dr. Ian Woollard, for reviewing the English version. Two anonymous reviewers provided valuable comments and suggestions.

\section{References}

Al Malek, S.A., \& Mohamed, A.M. O. (2005). Environmental impact assessment of shore oil spill on desalination plant. Desalination, 185, 9-30.

Areiqat, A., \& Mohamed K.A. (2005). Optimization of the negative impact of power and desalination plants on the ecosystem. Desalination, 185, 95-103.

Bilyard, G.R. (1987). The value of benthic infauna in marine pollution monitoring studies. Marine Pollution Bulletin, 18 (11), 581-585.

Buceta, J.L., Fernandez-Torquemada, Y., García, E., Invers, O., Mas, J., Romero, J., Ruiz, J.M., Ruiz-Mateo, A., Sabah, S., \& Sánchez-Lizaso. J.L. (2003). Investigación conjunta sobre la tolerancia de Posidonia oceanica a incrementos de salinidad. Ingeniería civil, 132, 111-116. 
Buchanan, J.B. (1984). Sediment análisis. In N.A. Holme \& A.D. McIntyre, Methods for the study of marine benthos(387p). $2^{\text {nd }}$ Ed. I.B.P. Handbook No. 16 London.

Castriota, L., Beltrano, A.M., Giambalvo, O., Vivota, P., \& Snseri, G. (2001). A oneyear study of the effects of a hyperhaline discharge from a desalination plant on the zoobenthic communities in the Ustica Island Marine Reserve (Southern Tyrrhenian Sea). In CIESM Congress (4 pp), Monte Carlo, Monaco.

Chesher, R.H. (1975). Biological impact of a large scale desalination plant at Key West, Florida. Elsevier Oceanography series, 2, 99-164.

Clarke, K.R., (1993). Non-parametric multivariate analyses of changes in community structure. Australian Journal of Ecology, 18, 117-143.

Clarke, K.R., \& Warwick, R.M. (1994). Changes in the marine communities: an approach to statistical analysis and interpretation. Natural Environment Research Council, U.K., pp.144.

Dethier, M.N., \& Schoch, G.C. (2006). Taxonomic sufficiency in distinguishing natural spatial patterns on a estuarine shoreline. Marine Ecology Progress Series, 306, 41-49

Einav, R., Harussi, K., \& Perry, D. (2002). The footprint of the desalination processes on the environment. Desalination, 152, 141-154. 
Elabbar, M.M., \& Elmabrouk, F.A. (2005).Environmental impact assessment for desalination plants in Libya. Case study: Benghazi North and Tobrouk desalination plants. Desalination, 185, 31-44.

Ellis, D. (1985). Taxonomic sufficiency in pollution assessment. Marine Pollution Bulletin, 16(12), 459.

Fernández Torquemada, Y., \& Sánchez Lizaso, J.L. (2005). Effects of salinity on leaf growth and survival of the Mediterranean seagrass Posidonia oceanica (L.) Delile. Journal of Experimental Marine Biology and Ecology, 320, 57-63.

Fernández Torquemada, Y.; González Correa, J.M.; Carratalá, A.\& Sánchez Lizaso, J.L. (2004). Medidas de atenuación del posible impacto ambiental del vertido de las desaladoras de ósmosis inversa: El ejemplo de Jávea. IV Congreso Ibérico sobre Gestión y Planificación del Agua Libro de resúmenes, 179-180.

Fernandez Torquemada, Y., Durako, M., \& Sánchez Lizaso, J.L. (2005a). Salinity effects and its possible interaction with $\mathrm{pH}$ and temperature variations on photosynthesis and growth of Halophila johnsonii Eiseman. Marine Biology, 148, 251260

Fernández-Torquemada, Y., Sánchez-Lizaso, J.L., \& González-Correa, J.M. (2005b). Preliminary results of the monitoring of the brine discharge produced by the SWRO desalination plant of Alicante (SE Spain). Desalination, 182, 395-402. 
Ferraro, S.P., \& Cole, F.A. (1992). Taxonomic level sufficient for assessing a moderate impact on macrobenthic communities in Puget Sound, Washington, USA. Canadian Journal of Fisheries and Aquatic Science, 49, 1184-1188.

Fränzle, O. (2006). Complex bioindication and environmental stress assessment. Ecological Indicators, 6, 114-136.

García, E., \& Ballesteros, E. (2001). El impacto de las plantas desalinizadoras sobre el medio marino: la salmuera en las comunidades bentónicas mediterráneas. In Conferencia internacional: El Plan Hidrológico Nacional y la Gestión Sostenible del Agua. Aspectos medioambientales, reutilización y desalación (10pp), Zaragoza.

García, C., \& Servera, J. (2003). Impacts of tourism development and water demand and beach degradation on the island of Mallorca (Spain). Geogr. Ann., 85A (3-4), 287300.

Höpner, T., \& Widdelberg, J. (1996). Elements of environmental impact studies on coastal desalination plants. Desalination, 108, 11-18.

Mabrook, B. (1994). Environmental impact of waste brine disposal of desalination plants, Red Sea, Egypt. Desalination, 97, 453-465.

Meerganz Von Medeazza, G.L. (2005). "Direct" and socially-induced environmental impacts of desalination. Desalination, 185, 57-70. 
Olsgard, F., Somerfield, P.J., \& Carr, M.R. (1997). Relationships between taxonomic resolution and data transformation in analyses of a macrobenthic community along an established pollution gradient. Marine Ecology Progress Series, 149, 173-181.

Purnama, A., Al-Barwani, H.H., \& Smith, R. (2005). Calculating the environmental cost seawater desalination in the Arabian marginal seas. Desalination, 185, 79-86.

Raventos, N., Macpherson, E., \& García-Rubiés, A. (2006). Effect of brine discharge from a desalination plant on macrobenthic communities in the NW Mediterranean. Marine Environmental Research, 62, 1-14.

Sadhwani, J.J, Veza, J.M., \& Santana, C. (2005). Case studies on environmental impact of seawater desalination. Desalination, 185, 1-8.

Underwood, A.J. (1981). Techniques of analysis of variance in experimental marine biology and ecology. Annu. Rev. Oceanogr. Mar. Biol, 19, 513-605.

Underwood, A.J. (1997). Experiments in ecology: their logical design and interpretation using analysis of variance. Cambridge: Cambridge University Press.

Vries, M.B., Delvigne, G.A.L., \& Thabet, R.A.H. (1997). Relocation of desalination plant's outfall in the $U . A$. E in order to minimise environmental damage. Madrid: I.D.A. World Congress on Desalination and Water Resurce. 
Weiss, J.M., \& Reice, S.R. (2005). The aggregation of impacts: using species-specific effects to infer community-level disturbances. Ecological Applications, 15(2), 599-617.

Warwick, R.M. (1988a). The level of taxonomic discrimination required to detect pollution effects on marine benthic communities. Marine Ecology Progress Series, 19, 259-268.

Warwick, R.M. (1988b). Analysis of community attributes of the macrobenthos of Frierfjord/Langesundfjord at taxonomic levels higher than species. Marine Ecology Progress Series, 46, 167-170. 
Table 1. Summary of physical characteristics at each station during each sampling time (O.M: organic matter; Grain sizes (gravel: $>2 \mathrm{~mm}$, coarse sand: $2 \mathrm{~mm}-500 \mu \mathrm{m}$, medium sand: $500 \mu \mathrm{m}$ - $250 \mu \mathrm{m}$, fine sand: $250 \mu \mathrm{m}-63 \mu \mathrm{m}$ and mud: $<63 \mu \mathrm{m})$ ).

Table 2: Results of ANOVAs of the structural parameters: abundance, number of taxonomic groups and diversity of the infaunal community $(*$ significant at $\mathrm{p}<0.05$; ** $\mathrm{p}<0.01 ; * * * \mathrm{p}<0.001 ;{ }^{\mathrm{ns}}$ no significant difference; RES= Residual; $\mathrm{F}$ of each factor= MS factor / MS residual because all the factors are orthogonal). 


\section{ACCEPTED MANUSCRIPT}

Table 1.

\begin{tabular}{|c|c|c|c|c|c|c|c|c|c|c|c|}
\hline Station & Year & Season & Salinity & $\operatorname{Depht}(\mathrm{m})$ & $\mathrm{pH}$ & $\begin{array}{l}\text { O.M } \\
(\%)\end{array}$ & $\begin{array}{c}\text { Gravel } \\
(\%)\end{array}$ & $\begin{array}{c}\text { Coarse } \\
\text { sand } \\
(\%)\end{array}$ & $\begin{array}{c}\text { Medium } \\
\text { sand } \\
(\%)\end{array}$ & $\begin{array}{l}\text { Fine } \\
\text { sand } \\
(\%)\end{array}$ & $\begin{array}{l}\text { Mud } \\
(\%)\end{array}$ \\
\hline \multirow{4}{*}{$\mathrm{A} 1$} & 2004 & Winter & 37.93 & 4 & 7.88 & 3.2 & 48 & 28 & 11 & 9 & 4 \\
\hline & & Summer & 38.38 & 4 & 7.34 & 5 & 5 & 9 & 15 & 49 & 22 \\
\hline & 2005 & Winter & 38.2 & 4 & 7.49 & 1.56 & 0.40 & 0.62 & 0.46 & 75.19 & 23.33 \\
\hline & & Summer & 37.4 & 4 & 7.76 & 6.35 & 10.2 & 5.1 & 8.9 & 63.6 & 12.2 \\
\hline \multirow{4}{*}{$\mathrm{A} 2$} & 2004 & Winter & 38.09 & 10 & 7.45 & 7.76 & 13 & 8 & 5 & 24 & 50 \\
\hline & & Summer & 37.64 & 10 & 7.52 & 6 & 5 & 5 & 6 & 41 & 43 \\
\hline & 2005 & Winter & 37.77 & 10 & 7.48 & 7.09 & 1.04 & 1.04 & 1.56 & 9.90 & 86.46 \\
\hline & & Summer & 37.3 & 10 & 7.45 & 2.41 & 31.6 & 27.1 & 10.6 & 21.3 & 9.3 \\
\hline \multirow{4}{*}{ A3 } & 2004 & Winter & 38.89 & 15 & 7.7 & 6.36 & 6 & 2 & 3 & 20 & 69 \\
\hline & & Summer & 38.095 & 15 & 7.51 & 5.4 & 7 & 3 & 4 & 34 & 52 \\
\hline & 2005 & Winter & 38.65 & 15 & 7.07 & 5.92 & 3.41 & 3.68 & 3.23 & 30.79 & 58.89 \\
\hline & & Summer & 37.5 & 15 & 7.14 & 5.06 & 2.8 & 2.6 & 2.3 & 31.2 & 61.1 \\
\hline \multirow{4}{*}{ B1 } & 2004 & Winter & 40.56 & 4 & 7.43 & 3.51 & 12 & 12 & 20 & 9 & 47 \\
\hline & & Summer & 40.66 & 4 & 7.2 & 3.4 & 3 & 4 & 9 & 49 & 35 \\
\hline & 2005 & Winter & 40.62 & 4 & 7.32 & 4.23 & 2.77 & 5.45 & 31.24 & 26.76 & 33.79 \\
\hline & & Summer & 40.69 & 4 & 7.36 & 2.36 & 8.50 & 8.44 & 29.97 & 33.99 & 19.09 \\
\hline \multirow{4}{*}{ B2 } & 2004 & Winter & 39.27 & 10 & 7.79 & 3 & 14 & 48 & 15 & 9 & 14 \\
\hline & & Summer & 38.65 & 10 & 7.44 & 6.5 & 7 & 18 & 6 & 25 & 44 \\
\hline & 2005 & Winter & 39.01 & 10 & 7.32 & 2.60 & 0.43 & 1.52 & 0.82 & 37.84 & 59.40 \\
\hline & & Summer & 38.51 & 10 & 7.65 & 2.42 & 44.43 & 45.64 & 6.41 & 1.88 & 1.64 \\
\hline \multirow{4}{*}{ B3 } & 2004 & Winter & 38.5 & 15 & 7.48 & 8.3 & 8 & 6 & 7 & 21 & 58 \\
\hline & & Summer & 37.9 & 15 & 7.42 & 10.4 & 5 & 7 & 5 & 29 & 54 \\
\hline & 2005 & Winter & 38.3 & 15 & 7.19 & 7.66 & 1.85 & 1.26 & 1.85 & 19.96 & 75.09 \\
\hline & & Summer & 37.7 & 15 & 7.01 & 6.32 & 7.87 & 4.67 & 5.40 & 26.53 & 55.54 \\
\hline \multirow{4}{*}{$\mathrm{C} 1$} & 2004 & Winter & 38.06 & 4 & 7.76 & 2.5 & 2 & 2 & 7 & 62 & 26 \\
\hline & & Summer & 37.88 & 4 & 7.68 & 1 & 1 & 1 & 4 & 86 & 8 \\
\hline & 2005 & Winter & 37.46 & 4 & 7.37 & 1.98 & 2.51 & 18.72 & 42.00 & 32.60 & 4.17 \\
\hline & & Summer & 37.1 & 4 & 7.76 & 1.13 & 0.20 & 2.58 & 9.02 & 77.38 & 10.83 \\
\hline \multirow{8}{*}{$\mathrm{C} 2$} & 2004 & Winter & 38.06 & 10 & 7.94 & 4.8 & 12 & 12 & 6 & 26 & 44 \\
\hline & & Summer & 37.88 & 10 & 7.4 & 3.7 & 1 & 1 & 4 & 19 & 70 \\
\hline & & & 37.46 & 10 & 7.29 & 6.02 & 4.11 & 8.94 & 8.23 & 15.38 & 63.33 \\
\hline & & Summer & 37.1 & 10 & 7.46 & 2.56 & 0.90 & 1.63 & 2.25 & 52.02 & 43.20 \\
\hline & & Winter & 38.64 & 15 & 7.75 & 8.3 & 10 & 5 & 4 & 24 & 57 \\
\hline & & Summer & 38.17 & 15 & 7.36 & 22.7 & 12 & 6 & 8 & 32 & 42 \\
\hline & 2005 & Winter & 38.15 & 15 & 7.33 & 5.05 & 1.36 & 3.65 & 3.08 & 31.09 & 60.82 \\
\hline & & Summer & 37.6 & 15 & 7.18 & 14.77 & 6.29 & 4.47 & 5.08 & 24.55 & 59.61 \\
\hline
\end{tabular}




\section{ACCEPTED MANUSCRIPT}

Table 2

\begin{tabular}{lccccccc}
\hline & \multicolumn{4}{c}{ Abundance } & \multicolumn{2}{c}{$\mathrm{N}^{\mathrm{o}}$ taxonomic groups } & \multicolumn{2}{c}{ Diversity } \\
\hline Source & DF & MS & $\mathrm{F}$ & $\mathrm{MS}$ & $\mathrm{F}$ & $\mathrm{MS}$ & $\mathrm{F}$ \\
\hline Year & 1 & 25294485.6 & $1.85^{\mathrm{ns}}$ & 4.8981 & $1.08^{\mathrm{ns}}$ & 0.0632 & $0.69^{\mathrm{ns}}$ \\
Season & 1 & 112812953 & $8.26^{* *}$ & 114.0833 & $25.04^{* * *}$ & 1.7141 & $18.73^{* * *}$ \\
Transect & 2 & 395607.263 & $0.03^{\mathrm{ns}}$ & 58.5278 & $12.85^{* * *}$ & 0.7992 & $8.73^{* * *}$ \\
Depth & 2 & 1445084.12 & $0.11^{\mathrm{ns}}$ & 32.25 & $7.08^{* *}$ & 0.1935 & $2.11^{\mathrm{ns}}$ \\
YexSe & 1 & 15737.4405 & $0^{\mathrm{ns}}$ & 0.0093 & $0^{\mathrm{ns}}$ & 0.4105 & $4.48^{*}$ \\
YexTr & 2 & 21457444.5 & $1.57^{\mathrm{ns}}$ & 5.8981 & $1.29^{\mathrm{ns}}$ & 0.6767 & $7.39^{* *}$ \\
YexDe & 2 & 24985633 & $1.83^{\mathrm{ns}}$ & 0.8981 & $0.2^{\mathrm{ns}}$ & 0.123 & $1.34^{\mathrm{ns}}$ \\
SexTr & 2 & 23764511 & $1.74^{\mathrm{ns}}$ & 4.0833 & $0.9^{\mathrm{ns}}$ & 0.4154 & $4.54^{*}$ \\
SexDe & 2 & 12835521.2 & $0.94^{\mathrm{ns}}$ & 2.8611 & $0.63^{\mathrm{ns}}$ & 0.1463 & $1.6^{\mathrm{ns}}$ \\
TrxDe & 4 & 23716670.1 & $1.74^{\mathrm{ns}}$ & 9.5694 & $2.1^{\mathrm{ns}}$ & 0.0703 & $0.77^{\mathrm{ns}}$ \\
YexSexTr & 2 & 55211626.9 & $4.04^{*}$ & 13.4537 & $2.95^{\mathrm{ns}}$ & 0.2842 & $3.11^{\mathrm{ns}}$ \\
YexSexDe & 2 & 39613646.9 & $2.9^{\mathrm{ns}}$ & 10.1759 & $2.23^{\mathrm{ns}}$ & 0.0531 & $0.58^{\mathrm{ns}}$ \\
YexTrxDe & 4 & 9170287.71 & $0.67^{\mathrm{ns}}$ & 13.6898 & $3.01^{*}$ & 0.8544 & $9.33^{* * *}$ \\
SexTrxDe & 4 & 13179859 & $0.97^{\mathrm{ns}}$ & 4.2361 & $0.93^{\mathrm{ns}}$ & 0.2661 & $2.91^{*}$ \\
YexSexTrxDe & 4 & 7051076.89 & $0.52^{\mathrm{ns}}$ & 8.912 & $1.96^{\mathrm{ns}}$ & 0.2972 & $3.25^{*}$ \\
RES & 72 & 13654843.5 & & 4.5556 & & 0.0915 & \\
TOTAL & 107 & & & & & & \\
\hline
\end{tabular}


Figure 1: Location of the sampling sites used in the study. $(B=$ transect next to the discharge, $A=$ transect located North of discharge, $C=$ transect located South of discharge; $1=$ sites located at 4 metres, $2=$ sites located at 10 metres, $3=$ sites located at 15 meters).

Figure 2: Percentage of the main taxonomic groups at each station in the different sampling times (W= winter, $\mathrm{S}=$ summer; 04= year 2004, 05= year 2005).

Figure 3. Mean abundance of infaunal community at all stations, for each seasonal period (winter and summer) and for each year (2004 and 2005).

Figure 4. Mean number of taxonomic groups at all stations, for each seasonal period (winter and summer) and for each year (2004 and 2005).

Figure 5. Mean diversity of infaunal community at all stations, for each seasonal period (winter and summer) and for each year (2004 and 2005).

Figure 6. MDS plot using Bray-Curtis similarities, using non transformed infaunal community abundance data. 


\section{ACCEPTED MANUSCRIPT}

Figure 7. Bubble plot correlating infaunal assemblages and abiotic factors (organic matter: bubble maximum $=22.7 \%$, bubble $\operatorname{minimum}=3.2 \%$; salinity: bubble $\max =41$ psu, bubble $\min =37 \mathrm{psu}$; depth: bubble $\max =15 \mathrm{~m}$, bubble $\min =4 \mathrm{~m}$; medium sand: bubble $\max =42 \%$, bubble $\min =0.46 \%$; fine sand: bubble $\max =77.38 \%$, bubble $\min =$ $9 \%$ and mud: bubble $\max =75.09 \%$, bubble $\min =4 \%)$. 


\section{ACCEPTED MANUSCRIPT}

Figura 1. Yoana del Pilar Ruso

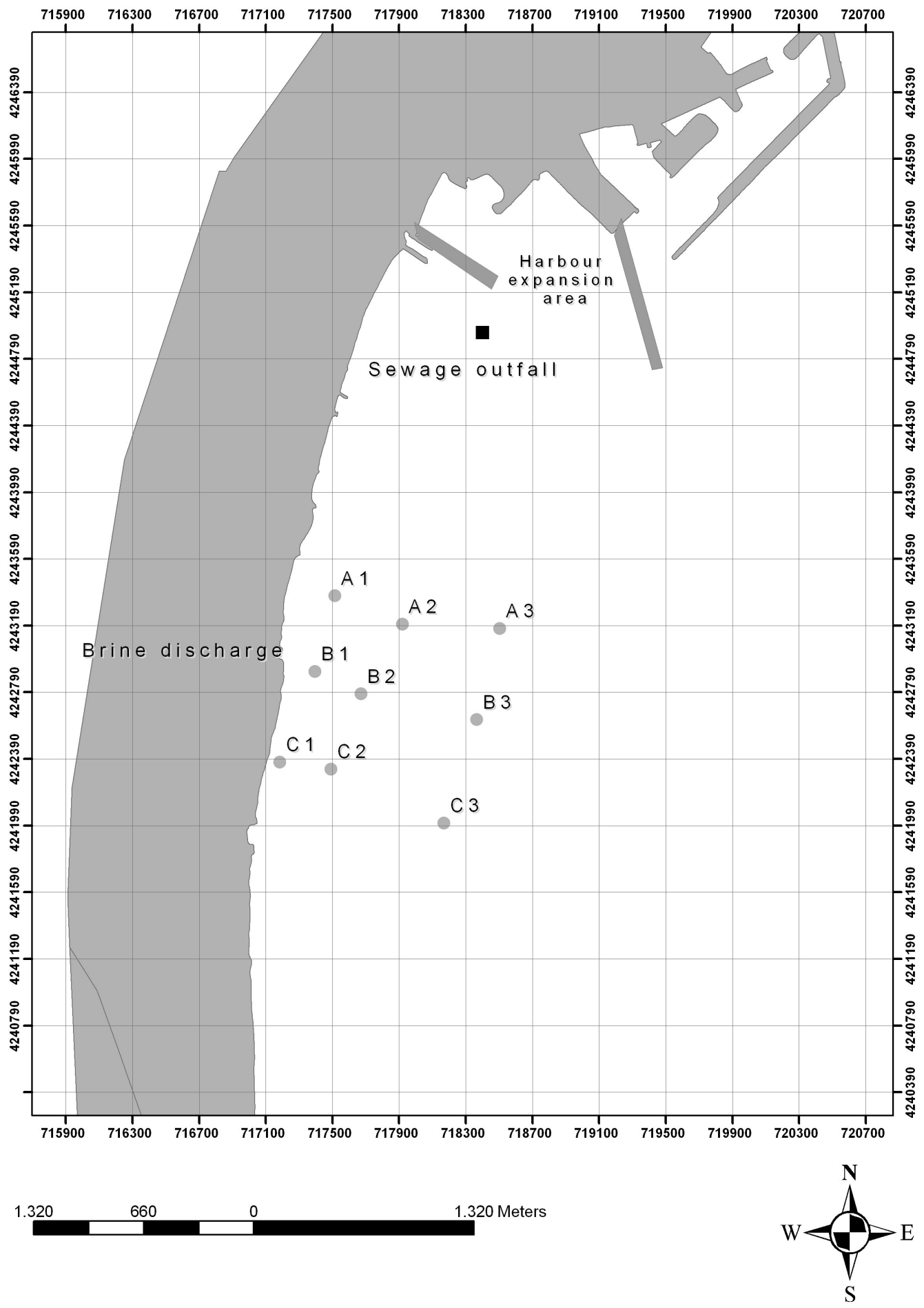




\section{ACCEPTED MANUSCRIPT}

Figure 2: Yoana del Pilar Ruso
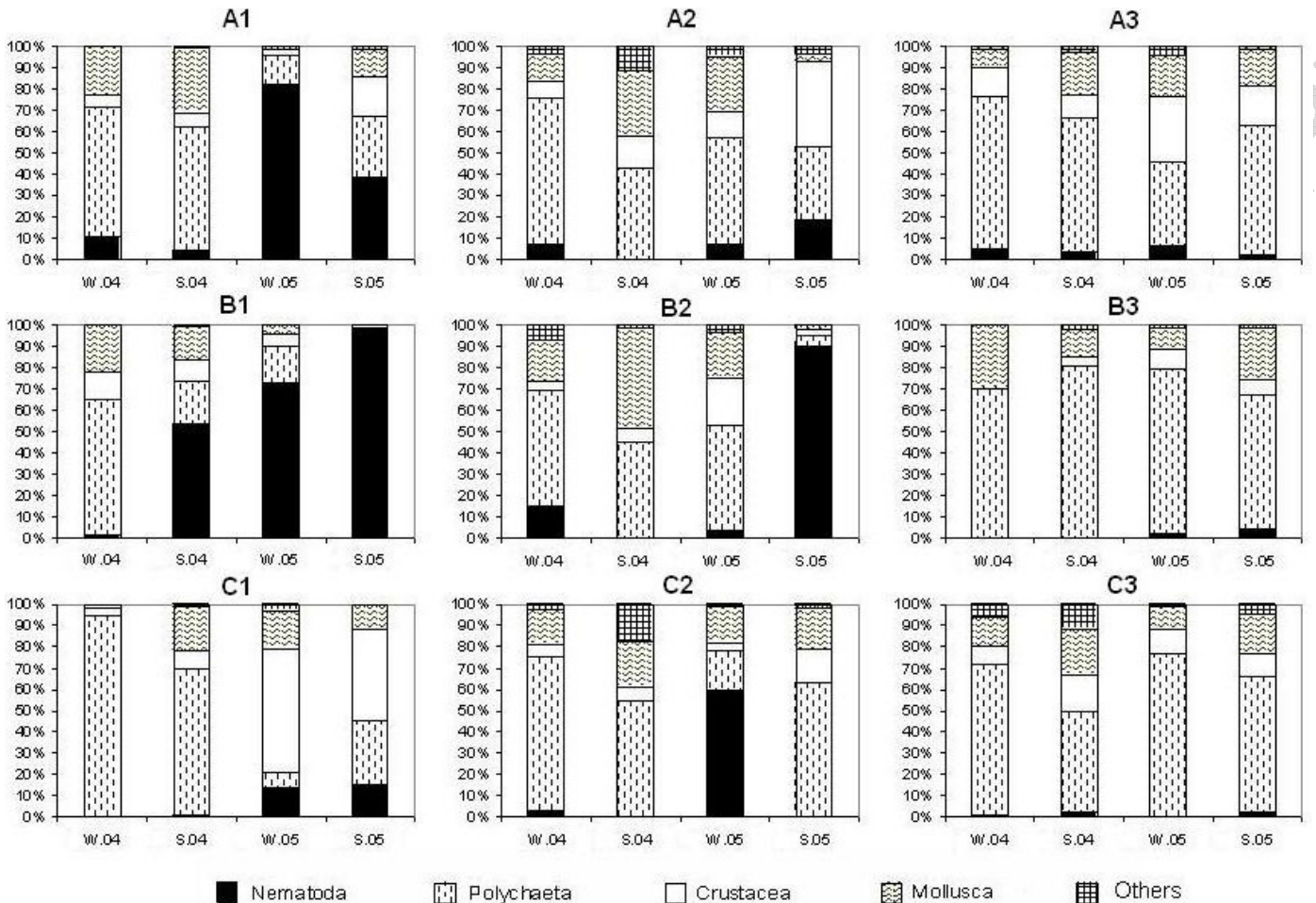

Nematoda

[四 Polychaeta

阙 Mollusca

曲 Others 
Figure 3. Yoana del Pilar Ruso
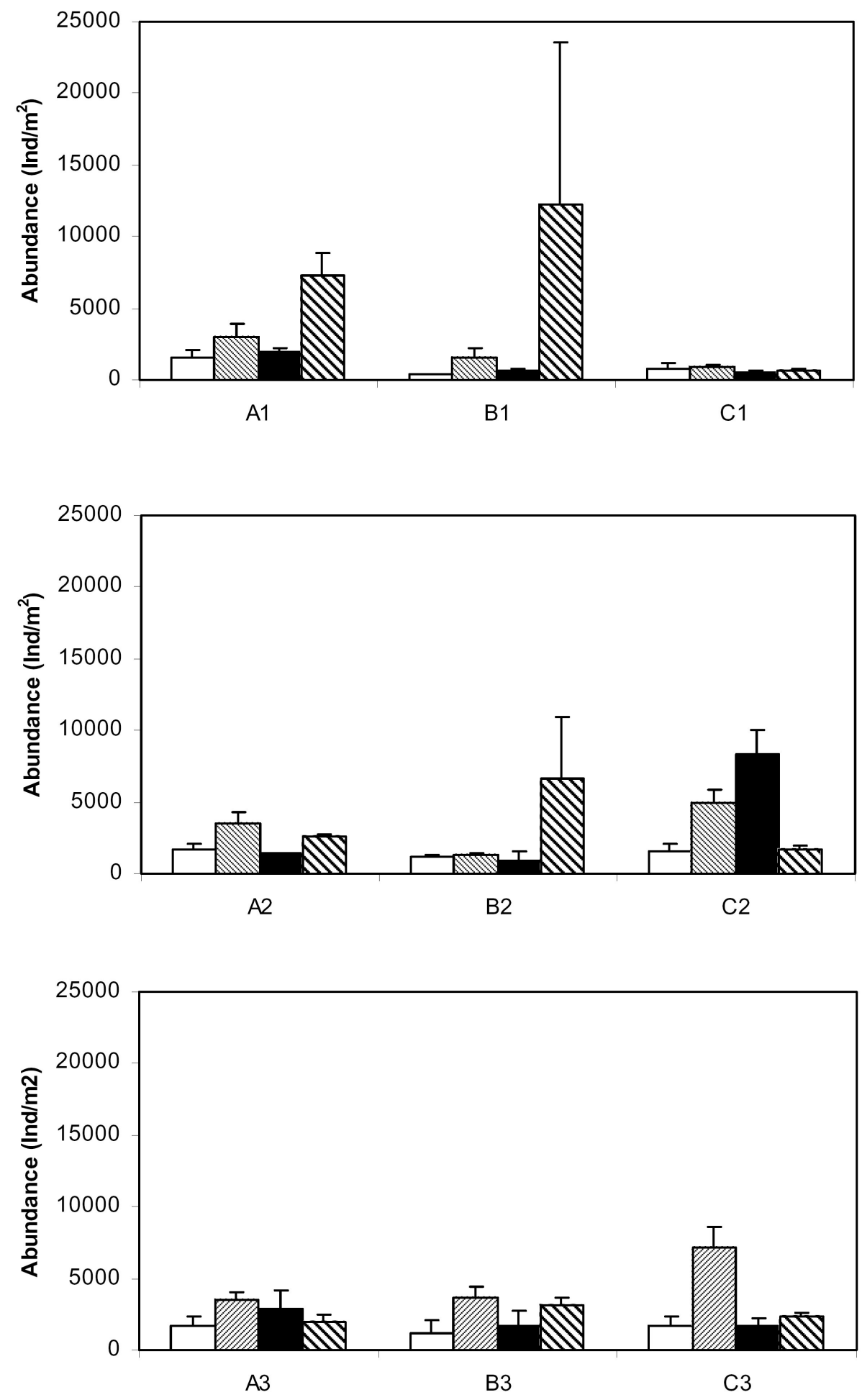

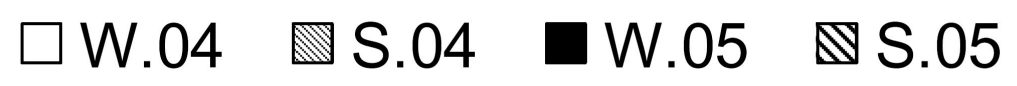


Figure 4. Yoana del Pilar Ruso
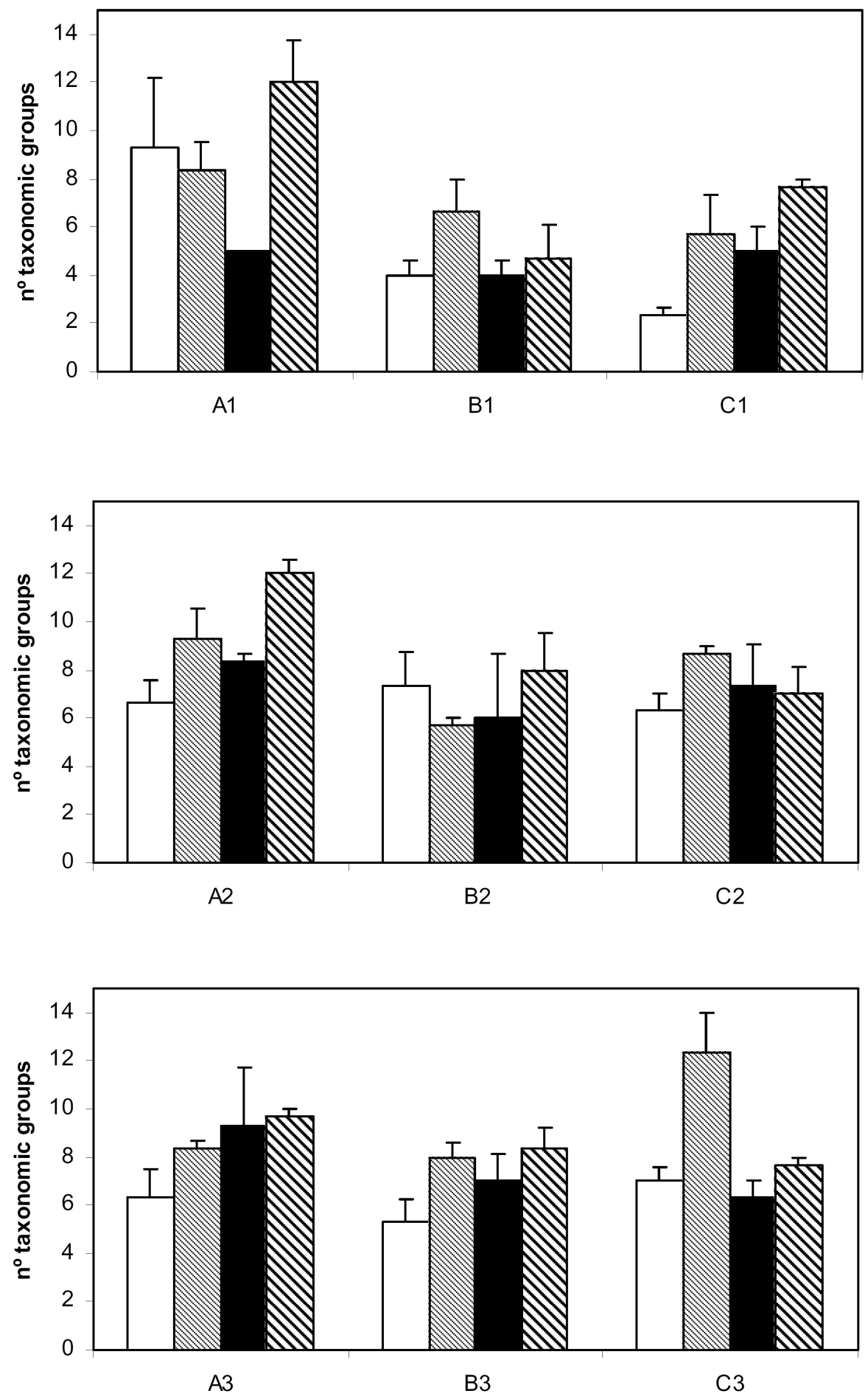

$\square \mathrm{W} .04 \quad \mathbb{S} .04 \quad \square \mathrm{W} .05 \mathbb{8} \mathrm{S} .05$ 
Figure 5. Yoana del Pilar Ruso
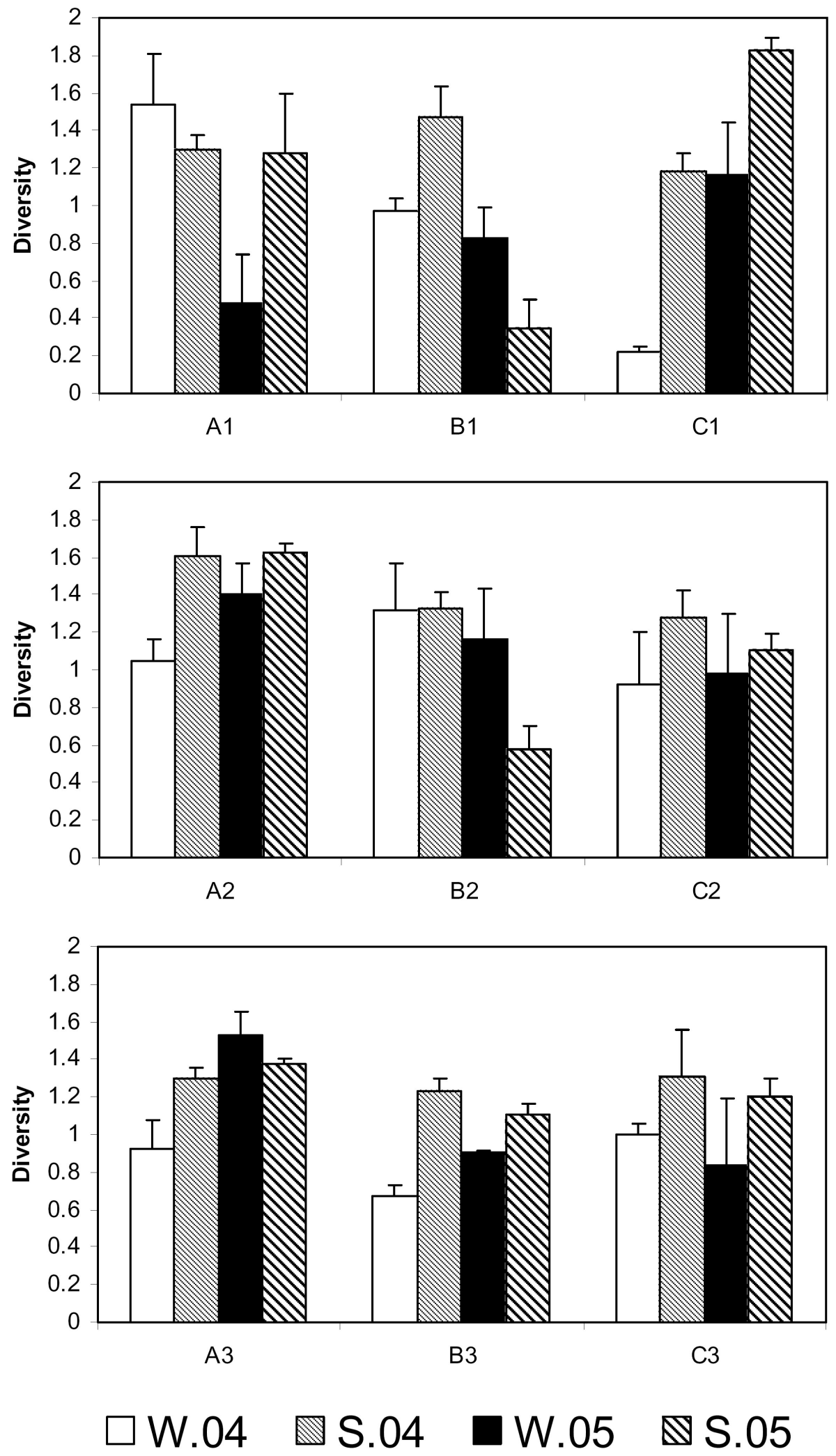


\section{ACCEPTED MANUSCRIPT}

Figure 6. Yoana del Pilar Ruso

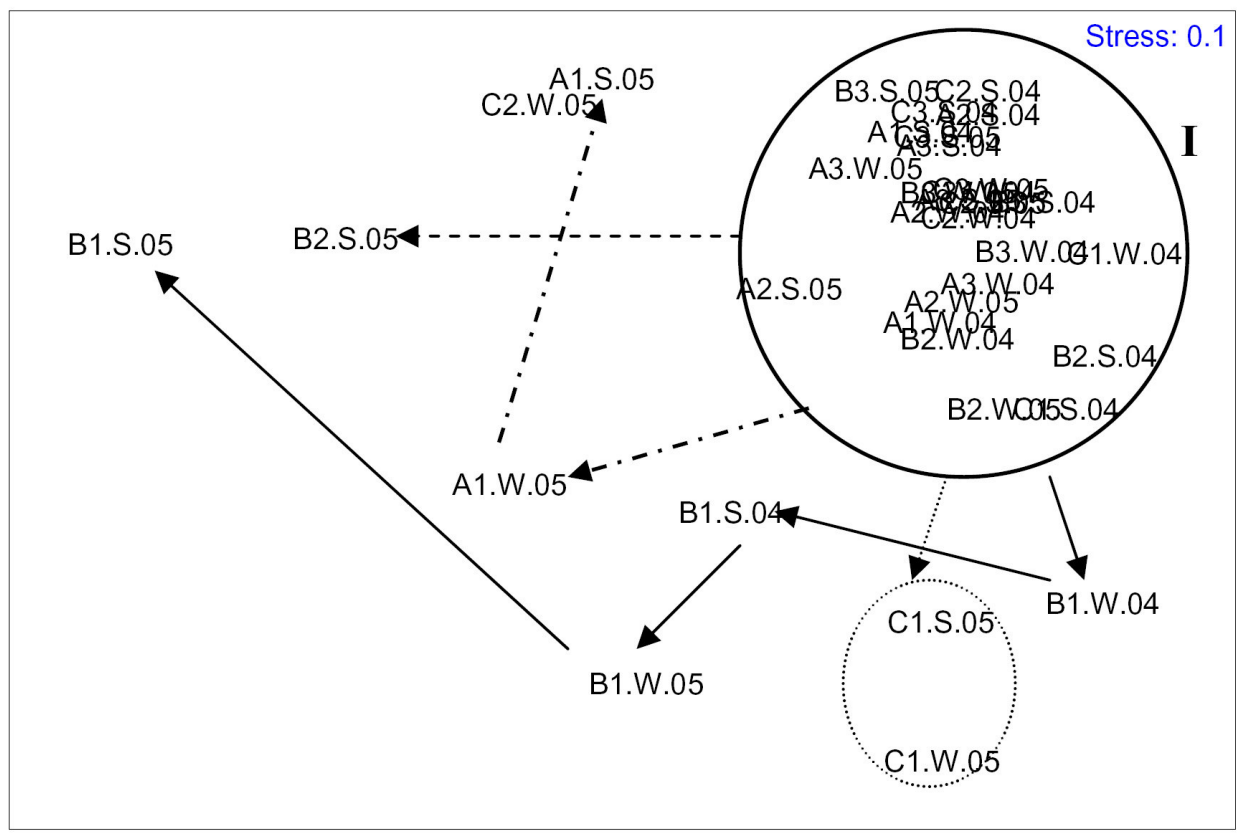


Figure 7. Yoana del Pilar Ruso

Organic matter

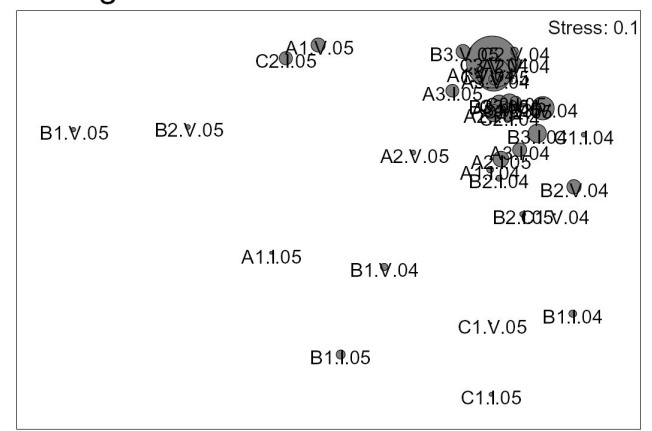

\section{Depth}

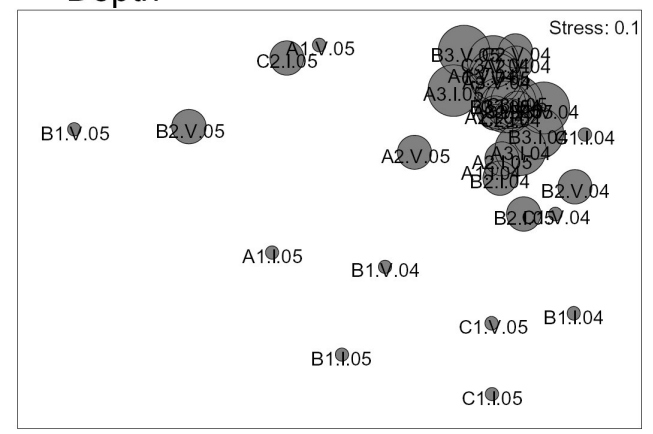

Fine sand

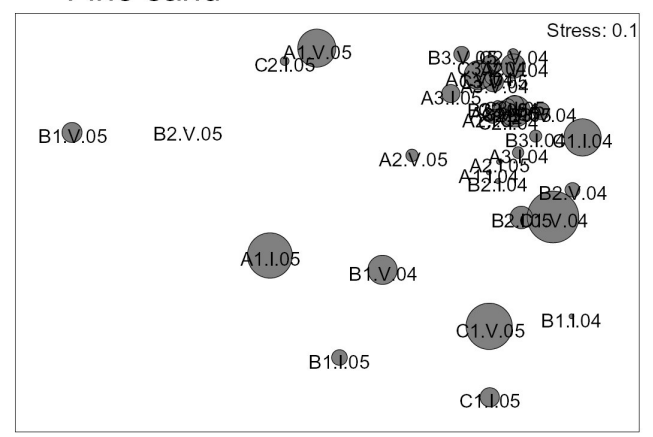

Salinity

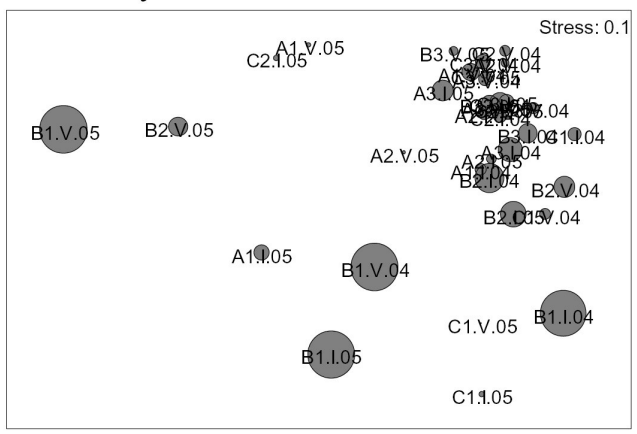

\section{Medium sand}

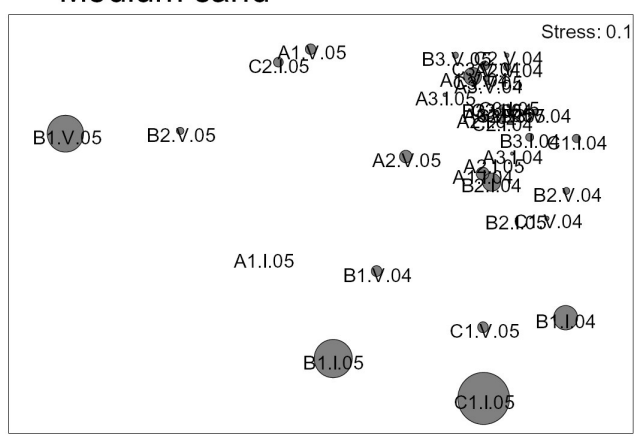

Mud

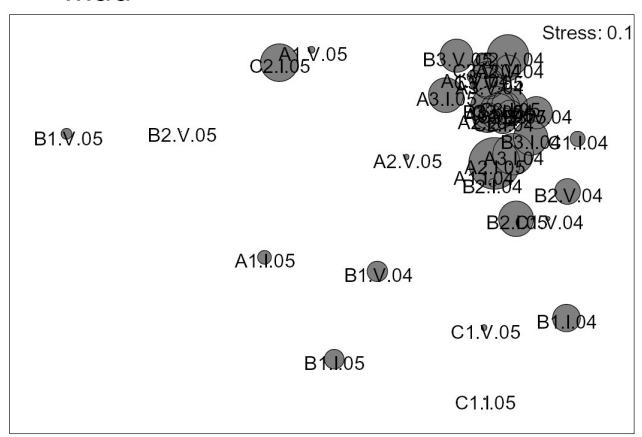

